ICOFOM Study Series

\title{
Defining Museum
}

Definiendo Museo

\section{Ann Davis}

\section{(2) OpenEdition}

1 Journals

Electronic version

URL: http://journals.openedition.org/iss/2385

DOI: $10.4000 /$ iss.2385

ISSN: 2306-4161

Publisher

ICOM - International Council of Museums

\section{Printed version}

Date of publication: 15 December 2020

Number of pages: 85-94

ISBN: 978-2-491997-27-4

ISSN: 2309-1290

Electronic reference

Ann Davis, "Defining Museum", ICOFOM Study Series [Online], 48-2 | 2020, Online since 26 January 2021, connection on 06 February 2021. URL: http://journals.openedition.org/iss/2385 ; DOI: https:// doi.org/10.4000/iss.2385 


\section{Defining Museum}

\section{Ann Davis}

A past president of ICOFOM - Canada

\section{ABSTRACT}

This paper presents a new definition of museum. In so doing, it departs from five principles: that the definition be short and simple; that it be relatively easy to translate into many languages; that it distinguishes museum from other collecting institutions; that it be flexible enough to allow room for local interpretation and local customs; and that it encompasses the full range of current museum ideologies. This definition seeks to identify the fundamentals of museums, the how, the why and the who, and eliminates the extraneous what and where.

Keywords: museum, definition, people, past, present, future.

\section{RESUMEN}

\section{Definiendo Museo}

Este documento presenta una nueva definición de museo. Al hacerlo, parte de cinco principios: que la definición sea breve y simple; que sea relativamente fácil de traducir a muchos idiomas; que distinga al museo de otras instituciones que también coleccionen objetos; que sea lo suficientemente flexible como para dejar espacio para interpretaciones y costumbres locales; y que abarque la gama completa de ideologías actuales sobre museos. Esta definición busca identificar los fundamentos de los museos, el cómo, el por qué y el quién, y elimina lo extraño, el qué y el dónde.

Palabras clave: museo, definición, personas, pasado, presente, futuro. 


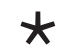

This paper will create a new definition of museum that encompasses the rich range of international museological practices. To do so, first there will be a brief exploration of what constitutes an appropriate definition. Then the paper will identify the salient features of museums, those which must be incorporated into a new definition. Finally, a new, somewhat radical definition will be proposed and analysed.

A definition is a statement of meaning of a term (Copi, 1982, p. 90). Definitions come in various categories, including intensional definitions, which give the sense of a term, and extensional definitions, which list the objects that that term describes. An intensional definition, sometimes called a connotative definition, specifies the conditions necessary for a thing to be a member of that specific set. It sets out the essence of something. For museums this might include a building which houses artifacts for study and enjoyment. On the other hand, an extensional definition, sometimes called a denotative definition, specifies its extension, a list of the objects that are members of that set (Cope, 1982). For example an extensional definition of museum could include the list of what institutions might be considered museums, such as historical monuments and zoos as well as scientific centres and art galleries, as outlined by François Mairesse in "The Term Museum" (20IO, pp.I9-20). The past ICOM definitions have been mostly intentional rather than extensional in nature, although a list of accepted museological organizations could be derived from such definitions. The definition proposed below will therefore be intentional in nature.

Certain rules have traditionally been applied to definitions, especially to intentional definitions. These include that the definition must contain the essential attributes of the thing being defined, that it must be not too wide or too narrow so that it does not miss anything out but also does not apply to anything else, and that it is presented in commonly understood terms (Copi, pp. IOO-IOI). In forming a definition of museum for an international audience, it is especially important to consider these three points, for any accepted definition will be widely use and translated into numerous languages (Mairesse, 20Io; Edson, 20I0). Two people who have carefully considered how to revise the ICOM definition of museum, François Mairesse and Gary Edson, agree. For Edson "Definitions are intended to briefly, and in the most precise terms, state what a word means" (2010, p. 60). Mairesse wants a definition "that is truly current, open and flexible" (2010, p. 56), favouring the kind of statement you find in a dictionary (Marshall, 2020). The ICOM committee tasked with creating a new definition (MDPP) explained that "A definition of museums should be clear and easy to understand, and should convey the spirit, the essence, the overall purposes of museums ...." (Sandahl, 2019). The definition 
should be clear and short because of how widely it is used, for well beyond the museum community, governments, funders and the public seek to know and understand what a museum is (Call for Papers, Sandahl, 2019; Mairesse, 20Io; Edson, 2010). It also must be flexible enough to accommodate the impressive diversity of museums around the world (Brown \& Mairesse, 20r8). In short, a new ICOM definition must be suitable for use all around the world, must be simple and straight forward, and must distinguish museums from other collecting bodies, such as archives and libraries.

What are the essential attributes of museum? One way to identify them is to look to past ICOM definitions, such as that of Georges Henri Riviere from I960:

"The museum is a permanent establishment, administered in the general interest, for the purpose of preserving, studying, enhancing by various means and, in particular, of exhibiting to the public for its delectation and instruction groups of objects and specimens of cultural value: artistic, historical, scientific and technological collections, botanical and zoological gardens and aquariums, etc."

that of 1974 , a distillation of the Rivière proposal with an important twist toward society and the elimination of the extensional listing:

"A museum is a non-profit making, permanent institution in the service of society and its development, and open to the public, which acquires, conserves, researches, communicates, and exhibits, for the purposes of study, education and enjoyment, material evidence of man and his environment;"

and that of 2007, in which collections are qualified to be tangible and intangible:

"A museum is a non-profit, permanent institution in the service of society and its development, open to the public, which acquires, conserves, researches, communicates and exhibits the tangible and intangible heritage of humanity and its environment for the purposes of education, study and enjoyment."

\section{9}

From these three definitions, and there are numerous others, it is possible to identify and isolate some main components of museums as ICOM has seen them in the past. These include governance (non-profit, permanent institution, open to the public); collecting (all three); exhibiting (all three); educating 
(all three); people (public) and purpose (1960 "delectation and instruction of ... objects"; "in the service of society and its development" 1974 and 2007). It appears, then that a new definition should include governance, collecting, exhibiting, educating, people and purpose.

Before looking more closely at this list, it is important to consider what else might or should be included in such a new definition: what are the current ideas. Much work in this regard has been done by the ICOM Committee for Museum Definition, Prospects and Potentials, commonly referred to by the acronym MDPP. Jetty Sandahl, the chair of this committee, noted that the old definitions do not include values and assumptions considered central today (Sandahl, 2017). Paramount here is the potentially important role of communities in museums. In December 2018, The MDPP recommended to the ICOM Executive Board a long list of elements that it felt were necessary parameters in a new definition (Sandahl, 20r9). These include museums' "value base", "collecting, preserving, documenting, researching, exhibiting and ... communicating the collections...", acknowledging "the crisis in nature and the imperative to develop and implement sustainable solutions", acknowledging "vastly different world views", acknowledging "deep societal inequalities and asymmetries of power and wealth", expressing "the unity of museums with the collaboration... [with] their communities", the commitment to be "meaningful meeting places and open diverse platforms for learning and exchange" and accountability and transparency (Sandahl, 2019). The Executive Board agreed to this list, many items of which were to facilitate and promote museums' social role. We should remember that the MDPP had a dual mandate, on the one hand, to "document and analyse prevalent societal trends and how these impact museums" and, on the other hand, to propose a new definition (Sandahl, 2019). Ultimately these two purposes were conflated by the MDPP - for this committee created the list of necessary parameters - such that the resulting draft definition, all 99 words of it, was a jumble of terms and concepts that met with little acceptance and did not adhere to the rules of a good definition outlined above. The goals were fine. The committee attempted to decolonize their proposed definition from the old definitions and anchor it "in a larger framework of general societal trends and issues of the $2 \mathrm{I}^{\mathrm{st}}$ century." Part of the effort, part of the recognition of the problem was "to counter the systemic European and Western dominance" (Sandahl, 20I9) that has so bedevilled ICOM and its committees for years. Unfortunately these many goals, and especially the specific list of required parameters, made the task of crafting a short, comprehensive definition that would satisfy Copi, Mairesse and Edson virtually impossible.

Opponents mustered. For the conservatives, the major point of contention was whether museums should have social or political responsibilities in addition to their stewardship of collections. A group of 24 nations, many from Europe and led by France, pushed to postpone the vote when the draft definition was presented in Kyoto in September 2019 (Marshall, 2020). Subsequently several members of the MDPP, including the chair, resigned. In July 2020, these 
former members wrote in a letter that "reducing these values, or dismissing them because they are "fashionable", "too political" or "divisive" essentially ignores much meaningful discourse regarding $2 \mathrm{I}^{\mathrm{st}}$ century museums definitions and museum practice." However many of the MDPP's required parameters, including the above values, more appropriately belong in other forms, such as ethics, mission and mandate statements, as ex-committee member François Mairesse argued (Marshall, 2020). The proposed definition swung too far to the social side such that many European museums did not see themselves in it. The MDPP made a good job of identifying the challenges in crafting a new definition for the $2 \mathrm{I}^{\mathrm{st}}$ century, but it failed to distill the many components it identified into a manageable, comprehensible statement while accommodating the more traditional museums. The task, then, is to produce a new definition that will satisfy both the conservatives and the socialists, both the Europeans and the non-Europeans, and be open enough to allow for the many points of view in the international museum community.

\section{A proposed definition}

By collecting, exhibiting and educating, the museum is a not-for-profit organization in which people preserve the past, probe the present and prepare the future.

This intentional definition seeks to identify the main characteristics of museum, the essential attributes that apply to all such bodies. The first half of this definition follows closely the old definitions; the second half is a different, perhaps radical new departure. The structure of this definition is straightforward, with the purpose of a museum identified as preserving the past, probing the present and preparing the future; the tools to do so are noted as collecting, exhibiting and educating, the administrative unit is identified as a not-forprofit organization, and the workers necessary to put all of this into effect are recorded as people. Not all museums will encompass all of these features all of the time: some museums concentrate on collecting and exhibiting and do little if any educating, while others are more interested in probing the present and preparing the future but spend little time preserving the past (Mairesse, 2010; Edson, 2010; Sandahl, 2019).

Missing in this definition is a whole range of specifics that might be included and have been included in past definitions. Rather, these are often implied here. For example, the three past definitions noted here stated that the museum was open to the public. Yet one might suggest that exhibiting and educating or interpreting are for the public, so visitors need not be separately specified. And it is certainly implied that preserving the past, probing the present and preparing the future are for the benefit of society. The 1974 definition identified the subjects covered more precisely as the "material evidence of man and his environment", gendered terminology that would be frowned upon today. Later, the 2007 definition felt it necessary to include in its scope the "tangible and intangible" heritage of humanity. These definitions, however, as François 
Mairesse (2010, p. 54) opines, have "not undergone any fundamental change" - and Edson (2010, p. 66) agrees.

Collecting, exhibiting and educating are generally accepted as the prime methods all museums use to convey their messages, the "how" they do their work. All previous definitions included these and they were deemed essential in MDPP's parameters. What the museum collects is left open, such that both the tangible and the intangible can be included. Also, the nature of the collection, be it automobiles, plants, scientific instruments or woodcuts, is not prescribed. The same breadth of possibilities should be assumed with exhibiting and interpreting. A museum may show exclusively its own collection, or may bring in travelling exhibitions or other types of displays. Education encompasses communication, interpretation and enjoyment. It may be directed by the museum, by the visitor or the community.

This definition substitutes not-for-profit for non-profit since it is recognized that many museums now-a-days seek to make some money though a shop, restaurant and membership in addition to the gate. Furthermore, museums may also look for financial donations to support acquisitions, programming and building. At the same time, the designation is needed for it is important to distinguish museums from commercial, for-profit institutions.

Another wording problem is what to call this body museum. The 1974 and 2007 ICOM definitions used institution, as do Mairesse, Edson and Brown (Mairesse, 20I0; Edson, 20I0; Brown and Mairesse, 2018). A substitute might be organization or establishment, the latter term used in 1960, but, in English institution is stronger and implies greater permanence. Bruno Brulon Soares (2018, p. I67) notes that, in some countries such as Brazil, an institution is a legal entity, requiring expensive bureaucratic legitimation, which prevents indigenous communities or traditional groups from creating their own recognized museums. The English equivalent might be corporation, which also requires legal recognition. Perhaps in Brazil this is a matter of the translation of the

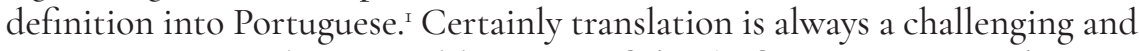
sensitive matter. The original language of the draft is germane, in this case English, recognizing that different terminological subtleties exist from one language to another, a problem to which Edson is particularly sensitive. In light of these concerns, this definition chose organization.

The single most important word in this new definition is people. Here is a word which is directed to subtlety addressing the MDPP's concerns about "asymmetries of power and wealth" and supporting "the unity of the expert

\footnotetext{
I. If the same word exists in two languages, the tendency is to assume that the meanings are the same in each language, which may be a dangerous assumption. A good translator knows the specific meaning in each language and, if they differ, can find an appropriate culturally specific synonym. Mediation in English and médiation in French are examples. In French in museums médiation means interpretation. In English mediation in museums means arbitration between two or more disputing persons. When used in English in museums mediation does not mean interpretation.
} 
role of museums with the collaboration and shared commitment, responsibility and authority in relation to their communities" (Sandahl, 2019). Today we engage with a range of museological theories. The expansion of theories in the late ig6os and early r970s is based on an expansion of the role of people, and especially those not on the museum staff. This started with a recognition that many, particularly those with lower incomes, did not visit museums. In the Anacostia museum, in a Black American neighbourhood, the programming shifted to attacking local problems such as rat infestation, drugs and unemployment. In Mexico, the Casa del Museo addressed hygiene and ancient Mexican culture. At about the same time, places that were not initially museums were developed as "territor[ies] for action" (Mairesse, 20Io, p. 37): ecomuseums. These first projects included Le Creusot in France and Haute-Beauce in Canada. Now community participation was the goal, for the purposes of meeting, exchange, discussion and education. This important expansion, this push to make museums for all, found expression in the 1972 Declaration of Santiago de Chile, and in new museology. A new definition must accommodate all major current approaches to museums and consider who has the power to manage the contents. On the one hand traditionalists are adamant that museums are primarily collecting institutions that exhibit and educate. On the other hand, others contend that the main purpose of museums is to advance society, to change the world for the better. Those who favour the social role of museums assert that the older, collection focus is hegemonic and promotes colonialism, that the museum staff dictate the nature and contents of collections, exhibitions and education. The newer group would like the museum to be socially interactive, to question established museological practices, to welcome a multiplicity of voices especially those external to the museum. These two divergent theories and everything between must find room in the definition such that all approaches are validated but none is prioritized. To allow space for all points of view, for museums at all stages of development, this definition does not identify who will make decisions, who will determine the purposes, and activities of the museum. The general term "people", rather than museum staff, opens the possibility of anyone and everyone in the community working with the museum to preserve, probe and plan. At the same time, it does not restrict a museum from maintaining complete control of contents if they so desire.

Another vital, different and possibly radical section of this new definition is purposes, to preserve the past, probe the present and prepare the future. Those purposes, the answer to the question why does a museum do what it does, must be defined in a fashion that covers every discipline and is broad enough to allow for change and expansion. Purpose should not be confused with subject matter, be that anthropology, science, history or art. Museums have traditionally been concerned with collecting and conserving the past. However, with the Declaration of Santiago de Chile and the advent of ecomuseums, the purpose of some museums was changing from conservation centres to tools for the benefit of local people, hence the addition in the 1974 definition of "in the service of society and its development". This was a shift in time, from 
the past to the present. Today classic museums propose to preserve the past. Most, but not all museums still focus on some aspect of the past. However, increasingly museums have an interest in social issues, which perforce changes the timeline from the past to the present, and perhaps the future.

Further to the notion of shifting time is a shift in the role of the public, or the visitor. Community and ecomuseums forced a new relationship between the population and the museum. Now the community, fed up with what they perceived to be elitist or esoteric, pushed for participation in the operation of the museum. In addition, we have new understandings of how the visitor apprehends the museum and its contents. This is in the present, seeing the past through the eyes of his or her particular present. John Falk (2016, p. 77) explains that museum visitors come partly to construct or to continue to construct self and identity, a process that involves integrating past and present. "...[A]s active meaning seekers, most museum visitors engaged in a degree of self-reflection and self-interpretation about their visit experience." This inevitably leads to a blurring of temporal boundaries: now the future is also germane alongside the present and the past. Those museums that specifically concentrate on the social may be more conscious of a present and future, as well as a past.

The advantage of reformatting purposes to a time line, rather than some statement about service to society, is that a time line is much more open, more fluid, and more able to accommodate every museum ideology without being judgmental. This definition is not directed toward any single museum theory or practice. It is freely available to the varied linguistic and cultural groups around the world (Brown \& Mairesse, 2018). It is neutral, unrestricted, and addresses that inclusive decolonization that the MDPP trumpeted. Ducking supporting one theoretical pole or the other, here the new definition suggests that many interpretations are valid, and that ICOM should not judge the worth of one theory over another. This fulfills the MDPP's desire that the new definition "should acknowledge and recognize with respect and consideration the vastly different world views, conditions and traditions under which museums work across the globe" (Sandahl, 20I9).

The effects of the combination of these new who - people, and new what - purposes, are many. It is fundamental to freeing museums, giving them a longer runway. It opens the purpose of any museum to national, regional and local determination and thus eliminates Eurocentric control. It overcomes colonialism; it puts the power in the hands of the museological organization. It allows but does not require attention to "climate crisis and the environment" (Sandahl, 20I9). If desired, it accepts that attention be paid to a whole range of other social issues, local ones, new ones. And in no way does it hinder those museums that want to emphasize their collections and not deal with difficult social concerns.

This new definition is built on clearly identifying the fundamentals of museums, the how, the why and the who, those characteristics without which the organi- 
zation would not be distinguishable from other collecting bodies. It focusses only on those fundamentals, eliminating the extraneous, such as the what or where. At the same time the definition is broad enough, general enough, to encompass virtually all the organizations that we recognize as museums and all theories that such organizations promote. W. Richard West, an ex-member of MDPP, wanted a new definition that allows room for the "fundamental, transformational earth-moving changes that are taking place in museums" (Marshall, 2020). The MDPP wanted a definition that enables "advocacy or activist positions relative to people, to human rights and social justice, as well as to nature as the - increasingly threatened - source of life" (Sandahl, 2019), while also allowing collections-based organizations to pursue their beliefs. This new definition does that.

\section{References}

Brown, K., \& Mairesse, F. (2018). The definition of the museum through its social role. Curator: The Museum Journal, 6I(4), 525-539.

Brulon Soares, B. (20r8). Museum in colonial contexts: the politics of defining an imported definition. In B. Brulon Soares, K. Brown \& O. Nazor (Eds.), Defining museums of the $21^{\text {st }}$ century: plural experiences (pp. 6I-79). Paris: ICOFOM.

Brulon Soares, B., Brown, K., \& Nazor, O. (Eds.). (2018). Defining museums of the $21^{\text {st }}$ century: plural experiences. Paris: ICOFOM.

Copi, I. (1982). Introduction to Logic. New York: Macmillan.

Davis, A., Desvallées, A., \& Mairesse, F. (Eds.) (20ro). What is a Museum? Munich, Germany: Verlag Dr. Müller-Straten.

Davis, A., \& Smeds, K. (Eds.) (20r6). Visiting the Visitor: An enquiry Into the Visitor Business in Museums. Bielefeld: transcript.

Edson, G. (20I0). Defining Museum. In A. Davis, A. Desvallées \& F. Mairesse (Eds.), What is a Museum? (pp. 59-67). Munich, Germany: Verlag Dr. Müller-Straten.

Falk, J. (20I6). Viewing the Museum Experience though an Identify Lens. In A. Davis \& K. Smeds (Eds.), Visiting the Visitor: An enquiry Into the Visitor Business in Museums (pp. 7I-88). Bielefeld: transcript, 2016.

Mairesse, F. (20ro). The Term Museum. In A. Davis, A. Desvallées \& F. Mairesse (Eds.), What is a Museum? (pp. 19-58). Munich, Germany: Verlag Dr. Müller-Straten.

Mairesse, F. (20II). Musée. In A. Desvallées \& F. Mairesse (Dirs.), Dictionnaire encyclopédique de muséologie (pp. 308-3I2). Paris: Armand Colin. 
Marshall, A. (2020). What is a Museum? A Dispute Erupts Over a New Def1nition. New York Times, August 6, 2020.

Sandahl, J. (2017, November 24). The Challenge of Revising the Museum Definition. Retrieved from https://icom.museum/en/news/the-challenge-of-revising-the-museum-definition/

Sandahl, J. (2019). The Museum Definition as the Backbone of ICOM. In J. Sandahl (Ed.), The museum definition. The backbone of museums [Special issue]. Museum International, 7I(28I-282), vi-9. 